\section{Über das unterschiedliche katalytische Verhalten einiger Thioharnstoff-Abkömmlinge}

Alfons Krause, mitbearbeitet von T. Weimann

Institut für anorganische Chemie der Universität Poznań (Polen)

(Z. Naturforschg. 21 b, 288-289 [1966] ; eingeg. am 4. Dezember 1965)

In Fortführung unserer Versuche über das katalytische Verhalten von artverwandten organischen Verbindungen ${ }^{1}$ wurden einige Abkömmlinge des Thioharnstoffs geprüft, die als durchweg gute und individuell wirkende Katalysatoren zu bezeichnen sind, was am Beispiel der peroxidatischen Indigocarmin-Entfärbung erwiesen wurde. Wir hatten Thioharnstoff, den symmetrischen und den nicht symmetrischen Dimethyl-Thioharns:off, Trimethyl-Thioharnstoff und Phenyl-Thioharnstoff zur Verfügung, die man in einer Menge von je $10 \mathrm{mg}$ in $25 \mathrm{~cm}^{3}$ dest. Wasser auflöst (x) und mit $25 \mathrm{~cm}^{3} \quad \mathrm{H}_{2} \mathrm{O}_{2}$ (1,2-proz.) sowie mit $10 \mathrm{~cm}^{3}$ Indigocarminlösung (= $=3,3 \mathrm{mg}$ Farbstoff) bei $37^{\circ}$ versetzt. Falls noch $\mathrm{Co}^{2 \oplus}$ - oder $\mathrm{Fe}^{3 \oplus}$-Promotorionen (in $1 \mathrm{~cm}^{3}$ $\mathrm{CoCl}_{2}$ - bzw. $1 \mathrm{~cm}^{3} \mathrm{FeCl}_{3}$-Lösung) verwendet werden, erfolgt ihr Zusatz an der mit (x) bezeichneten Stelle. Das einmal gründlich umgeschwenkte Reaktionsgemisch verbleibt zwecks Ermittlung der Entfärbungszeit ohne weitere Konvektion im Wasserthermostaten bei $37^{\circ}$. Da man in ein und demselben Reaktionsgemisch immer neue Farbstoffportionen laufend entfärben kann, so steht der homogenkatalytische Charakter dieser Reaktion außer Frage.

Wie aus Tab. 1 ersichtlich, sind Trimethyl-thioharnstoff und Phenyl-thioharnstoff die relativ besten Katalysatoren, während der Thioharnstoff selbst weit weniger aktiv ist. Daraus folgt, daß die $\mathrm{S}$ - und $\mathrm{NH}_{2}$-Gruppen keineswegs allein für das katalytische Geschehen verantwortlich sind. Es ist vielmehr zu bedenken, daß die genannten Verbindungen eher zu den latenten bzw. potentiellen Peroxidasemodellen gehören ${ }^{2}$, die als solche erst in dem $\mathrm{H}_{2} \mathrm{O}_{2}$-haltigen Reaktionsmedium ihre katalysatorischen Fähigkeiten erwerben oder zumindest verstärken können. Dabei dürften die $\mathrm{CH}_{3}$ - und die
$\mathrm{C}_{6} \mathrm{H}_{5}$-Gruppen in Angriff genommen werden, womit zugleich die Reaktionsfähigkeit ihrer H-Atome zur Diskussion steht, die in dieser Hinsicht durchaus nicht als gleichwertig zu betrachten sind. Wenn z. B., wie schon erwähnt, der Phenyl-thioharnstoff ein ausgezeichneter Katalysator ist, so deutet das mit ziemlicher Sicherheit darauf hin, daß infolge oxidativer Einwirkung von $\mathrm{H}_{2} \mathrm{O}_{2} \mathrm{OH}$-Wirkgruppen entstehen oder auch - infolge Dehydrierung - vorübergehend C-Radikale auftreten, die für einen Elektronentransfer einsatzbereit sind, woraufhin die katalytische Umsetzung in Gang kommt ${ }^{2}$. Ganz ähnlich liegen die Verhältnisse, wenn es sich um den Trimethyl-thioharnstoff handelt, wogegen die beiden Dimethyl-thioharnstoffe weniger gut katalysieren. Man könnte zunächst annehmen, daß die Zahl der Methylgruppen hierbei ausschlaggebend ist, doch sind diese Überlegungen nicht stichhaltig, da der symmetrische Dimethyl-thioharnstoff ein nur schwacher Katalysator ist, der in seiner Wirkung weit hinter dem Thioharnstoff zurückbleibt (Tab. 1). Die beiden Methylgruppen üben demnach in ihrer symmetrischen Stellung eine Art Blockadewirkung aus, was - strukturchemisch betrachtet - sicherlich bemerkenswert ist. Doch stehen solche Fakten keineswegs vereinzelt da und wurden erst kürzlich an bestimmten Nitroverbindungen sowie am $\beta$-Naphthylamin beobachtet, welche sich unerwartet als ausgesprochene Hemmkörper betätigten $^{3}$, so daß gerade am Rande der katalytischen Versuche auch gewisse strukturelle Eigentümlichkeiten dieser Stoffklassen sichtbar werden. Im Einklang mit diesen Erwägungen ist noch zu bemerken, daß man auf katalytischer Grundlage sehr schön die beiden Dimethyl-thioharnstoffe unterscheiden kann, was immerhin beachtenswert ist (Tab. 1). Damit hat sich in letzter Zeit die Zahl der katalytisch erfaßten subtilen Isomerieformen beträchtlich vergrößert, wofür als Beispiele Sorbit und Mannit ${ }^{4}$, Anthracen und Phenanthren ${ }^{5}$, Fumar- und Maleinsäure ${ }^{6}$ sowie noch Camphersäure und Iso-Camphersäure ${ }^{7}$ zu nennen sind.

Was die verwendeten Promotorionen anbetrifft, so wirkt $\mathrm{Fe}^{3 \oplus}\left(10^{-5} \mathrm{~g}\right.$, in einer Verdünnung von $1: 6 \mathrm{Mil}$ lionen) stärker als $\mathrm{Co}^{2 \oplus}\left(10^{-3} \mathrm{~g}\right.$, in einer Verdünnung

\begin{tabular}{|c|c|c|c|c|c|c|c|c|}
\hline $\begin{array}{l}(1) \\
335\end{array}$ & $\begin{array}{c}\text { (1) }+\mathrm{Fe}^{3 \oplus} \\
210\end{array}$ & $\begin{array}{c}(1)+\mathrm{Co}^{2} \oplus \\
365\end{array}$ & $\begin{array}{l}(2) \\
620\end{array}$ & $\begin{array}{c}(2)+\mathrm{Fe}^{3 \oplus} \\
300\end{array}$ & $\begin{array}{c}(2)+\mathrm{Co}^{2} \oplus \\
430\end{array}$ & $\begin{array}{l}(3) \\
265\end{array}$ & $\begin{array}{c}(3)+\mathrm{Fe}^{3 \oplus} \\
130\end{array}$ & $\begin{array}{c}(3)+\mathrm{Co}^{2} \oplus \\
200\end{array}$ \\
\hline (4) & $(4)+\mathrm{Fe}^{3 \oplus}$ & $(4)+\mathrm{Co}^{2} \oplus$ & (5) & $(5)+\mathrm{Fe}^{3 \oplus}$ & $(5)+\mathrm{Co}^{2} \oplus$ & $\begin{array}{l}\mathrm{Fe}^{3 \oplus} \\
\text { allein }\end{array}$ & $\begin{array}{l}\mathrm{Co}^{2} \oplus \\
\text { allein }\end{array}$ & Blindprobe \\
\hline 65 & 60 & 70 & 85 & 60 & 65 & 650 & 1050 & 1450 \\
\hline
\end{tabular}

Tab. 1. Peroxidatische Indigocarmin-Entfärbung bei $37^{\circ}$ an (1) Thioharnstoff, (2) symmetr. Dimethyl-thioharnstoff, (3) nicht symmetr. Dimethyl-thioharnstoff, (4) Trimethyl-thioharnstoff und (5) Phenyl-thioharnstoff (je $10 \mathrm{mg}$ ) bei Zusatz von $0,01 \mathrm{mg} \mathrm{Fe}{ }^{\oplus}$ oder $1 \mathrm{mg} \mathrm{Co}{ }^{2 \oplus}$. Angegeben ist die Entfärbungszeit in Minuten.

1 Vgl. A. Krause u. Mitarb., Z. Naturforschg. 20 b, 922 [1965]; Naturwissenschaften 52, 158 [1965]; Mh. Chem., im Druck.

2 Vgl. A. Krause, Z. Naturforschg. 20 b, 627 [1965]; Z. Naturforschg. 21 b, 189 [1966].

3 A. Krause u. Mitarb., noch nicht veröffentlicht.
4 A. Krause u. L. Łomozik, Z. Naturforschg. 21 b, 86 [1966]. 5 A. Krause u. E. Nowakowski, noch nicht veröffentlicht.

6 A. Krause u. L. Wachowski, Experientia [Basel] 21. 618 [1965].

7 A. Krause u. J. Orlikowska, Z. Chem., im Druck. 
von 1:60000). Doch ist das durchaus nicht als Regel zu betrachten, da Phenyl-thioharnstoff nur wenig und der Trimethyl-thioharnstoff gar nicht durch die beiden Ionen aktiviert wird. $\mathrm{Co}^{2 \oplus}$-Ion an Thioharnstoff hemmt sogar etwas die Indigocarmin-Oxidation. Es ist bezeichnend, daß gerade der symmetrische Dimethyl-thioharnstoff, der relativ schwächste Katalysator dieser Reihe, besonders ergiebig von der genannten Aktivie- rung Gebrauch macht (Tab. 1). Das ist so zu erklären, daß solchenfalls aller Wahrscheinlichkeit nach fehlgeordnete Komplexverbindungen mit $\mathrm{Fe}$ oder Co entstehen, die wegen ihrer Radikalstruktur einen brauchbaren Katalysator abgeben können. Wenn dagegen ein gesättigter bzw. vollzähliger (radikalloser) Komplex aufkommt, so ist in der Regel mit einer nicht aktiven oder wenig aktiven Verbindung zu rechnen.

\section{The Facile Inversion of Nitrogen-, Phosphorus- and Sulphur-Bridged Binuclear Carbonyl and Nitrosyl Complexes}

\author{
Mushtaq Ahmad, Robert Bruce, and Graham Knox \\ Department of Pure and Applied Chemistry, University \\ of Strathclyde, Glasgow, C. 1., Scotland \\ (Z. Naturforschg. 21 b, 289 [1966] ; eingegangen am 14. Januar 1966)
}

Binuclear complexes, where the metal atoms are bridged by arsenic ${ }^{1}$, phosphorus ${ }^{2}$ or sulphur ${ }^{3}$ containing ligands, have attracted considerable attention especially since such ligands impart comparative stability to the resulting compounds. It has been established that the geometry of several such complexes allows the separation ${ }^{4}$ of isomers, but in all cases a maximum of two geometrical isomers only have been found, irrespective of the theoretically possible number.

An examination of a large variety of systems reveals that the pairs of isomers appear to fall into two categories; thus from each pure isomer one obtains (a) equilibrium mixtures of both isomers or (b) essentially complete transformation of the less stable to the thermodynamically favoured isomer. The energy requirements for these processes are quite variable but always modest (i.e. half life period at $80^{\circ}$ less than $12 \mathrm{~h})$. These observations have considerable theoretical and synthetic significance.

Examples of type (a) are (i) $\left[\mathrm{C}_{5} \mathrm{H}_{5} \mathrm{Cr}(\mathrm{NO}) \mathrm{NMe}_{2}\right]_{2}{ }^{5}$ (ii) $\left[\mathrm{MeSFe}(\mathrm{CO})_{3}\right]_{2}{ }^{4 i}$ and (iii) $\left[\mathrm{C}_{5} \mathrm{H}_{5} \mathrm{NiSMe}\right]_{2}{ }^{6}$, the latter undergoing rapid equilibration even at ambient temperature; example (i) is the most difficult to equilibrate. As expected, the equilibria for (i) and (ii) favour the trans isomers in the temperature range studied $\left(25-80^{\circ}\right)$. Isomers (i) are the first members of a new class of complexes with bridging amido groups.

Examples of type (b) include (iv) $\left[\mathrm{C}_{5} \mathrm{H}_{5} \mathrm{Fe}(\mathrm{CO}) \mathrm{SR}\right]_{2}{ }^{4 \mathrm{c}}$ $(\mathrm{R}=\mathrm{Me}, \mathrm{Er}, \mathrm{Ph})$, (vi) $\left[\mathrm{C}_{5} \mathrm{H}_{5} \mathrm{Fe}(\mathrm{CO}) \mathrm{PPh}_{2}\right]_{2}{ }^{4 \mathrm{~b}}$ and probably (vii) $\left[\mathrm{MeSFe}(\mathrm{NO})_{2}\right]_{2}{ }^{7}$. With the exception

1 R. G. Hayter, Inorg. Chem. 2, 1031 [1963] ; R. G. Hayter and L. F. Williams, J. inorg. nuclear Chem. 26, 1977 [1964], and previous papers.

2 M. L. H. Green and J. T. Moelwyn-Hughes, Z. Naturforschg. 17 b, 783 [1962]; R. G. Hayter, J. Amer. chem. Soc. 86, 823 [1964]; D. T. Thомpson, J. organometallic Chem. 4, 74 [1965]; W. Hieber and E. Winter, Chem. Ber. 97, 1037 [1964]; K. Issleib and M. KeIL, Z. anorg. allg. Chem. 333, 10 [1964]. of (iii) and (vii), in every case the pure isomers have been separated and characterised.

In the absence of structural data the course of isomerisation of (iii), (iv) and (v) is not known, and is complicated by the number of possible geometrical isomers [e.g. at least five each for (iv) and (v)]. It is not clear why only two isomers are found in such cases, although this deficiency may be attributed to steric, kinetic, or thermodynamic limitations imposed during preparation; separately each of these factors is important. Isomerisation may occur at the bridging groups as in (ii) and (vii), where the methyl thio groups have different environments in the cis and trans isomers, or at the metal atoms as in (i) and (vi), where the cyclopentadienyl groups may adopt a cis or trans configuration. These conversions can be followed by NMR and/or IR techniques. However it is also possible that the unrecognisable complete inversion of terminal and bridging groups occur simultaneously. It is pertinent to note that while isomerisations of (ii) and (vii) may occur via an intramolecular path involving cleavage of one metal-bridging ligand bond and rotation of the $\mathrm{SMe}$ group, intramolecular isomerisation of (vi) must involve complete inversion of configuration at one iron atom.

The full mechanistic, kinetic and thermodynamic consequences of these transformations will be reported later.

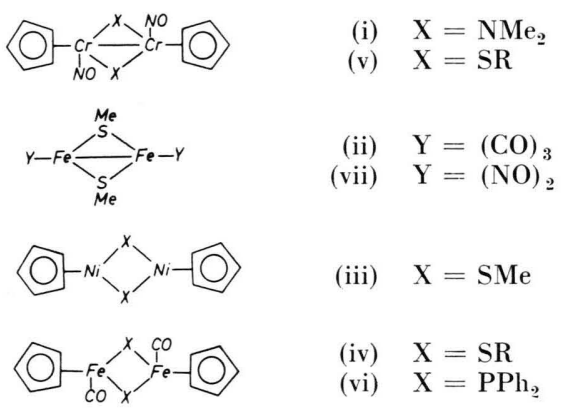

3 W. Hieber and A. Zeidler, Z. anorg. allg. Chem. 329, 92 [1964] ; P. M. Treichel, J. H. Morris, and F. G. A. Stone, J. chem. Soc. [London] 1963, 720, and previous references cited therein.

4 (a) R. B. King, J. Amer. chem. Soc. 84, 2460 [1962] ; (b) R. G. Hayter, J. Amer. chem. Soc. 85, 3120 [1963]; (c) M. Ahmad, R. Bruce, and G. R. Knox, J. organometallic Chem., in press.

5 M. Ahmad, unpublished results.

6 W. K. Schropp, J. inorg. nuclear Chem. 24, 1688 [1962].

7 R. Bruce, unpublished results. 